\title{
Exploring the practices of secondary school teachers in preparing for classroom observation amidst the new normal of education
}

Kevin Caratiquit $^{{ }^{*},}$, Reynel Pablo ${ }^{2}$

Lal-lo National High School, Lal-lo, Cagayan, Philippines ${ }^{1 *}$

Licerio Antiporda Sr. National High School, Buguey, Cagayan, Philippines ${ }^{2}$

kevin.caratiquit@deped.gov.ph ${ }^{I^{*}}$,reynel.pablo@deped.gov.ph ${ }^{2}$

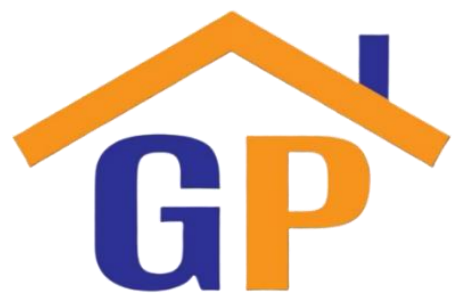

Article History

Received on 25 June 2021

Revised on 15 August 2021

Accepted on 18 August 2021

\begin{abstract}
Purpose: This study aimed to explore the practices of secondary public school teachers in preparing for classroom observation amidst the new normal of education. The emphasis of this study was drawn from the central question, "What are the practices of secondary public school teachers in preparing for classroom observation amidst the new normal of education?".
\end{abstract}

Research Methodology: This study used a qualitative research design. It employed a phenomenology design to explore the practices of secondary public school teachers in preparing the new normal classroom observation.

Results: Teachers believe that classroom observation is a measuring tool for achieving their professional goals or performance level. They also think that classroom observation can evaluate and assess the students' learning outcomes effectively and efficiently.

Limitations: This study was limited to 22 secondary public school teachers in Cagayan, Philippines.

Contribution: It can be helpful for teachers to improve their teaching techniques, strategies, methods, and instructional materials to be used amid this new normal of education.

Keyword: Classroom observation, Teachers' performance, New normal education

How to Cite: Caratiquit, K., \& Pablo, R. (2021). Exploring the practices of secondary school teachers in preparing for classroom observation amidst the new normal of education. Journal of Social, Humanity, and Education, 1(4), 281-296.

\section{Introduction}

COVID-19 has been declared a public health emergency. This infection is caused by a newly discovered coronavirus (SARS-CoV-2, formerly known as 2019-nCoV). It has attracted global attention as a result of the pandemic's vast growth and the imperative of eradicating the virus and flattening the infectious disease curve (Guo, Cao, Hong, Tan, Chen, Jin, Tan, Wang, \& Yan, Y. (2020). There have been school closures in many countries. Policymakers must decide whether to close or keep schools open in the face of a crisis. In many families throughout the world, homeschooling has a significant impact on parents' productive output, children's social lifestyles, and learning. Education is moving online on an unprecedented scale.

Academic experts began considering the traditional method of face-to-face instruction in the aftermath of the pandemic. They began researching distance education as a viable option for filling the classroom void for three to four months, thereby lowering the risk of infectious disease among learners prior to the resumption of traditional activities, mentioned by Kaur in 2020 (As cited by Adnan \& Anwar (2020). With that, as student assessments move online, this leads to significant 
careful planning and uncertainty for everyone. Numerous assessments have been altogether canceled. Notably, these disturbances will not occur infrequently. They are almost sure to have long-term implications for the affected collaborators and to exacerbate inequality.

Distance learning emphasizes the lack of physical meetings between instructors and learners; these can be influenced by digital communication in the form of visual media, the demonstration of text material, illustrations, and images in real-time or on a delayed basis (Griffiths, 2016). For years, the Philippine Education System remained traditional but has evolved to meet the needs of the new generation. Indeed, long before this "new normal" became apparent, teachers and students were already utilizing the internet, computers, and other technologies in the classroom. However, the distinction is between a face-to-face class and the virtual classes, now the "new normal." The Department of Education established three modes of delivery for learning in the new normal. These are referred to as Blended Learning, Distance Learning, and Homeschooling.

Distance learning's first mode of instruction, which comes in three varieties. The first is modular distance learning. A module is a unit of instruction that contains knowledge about a subject, focuses on learning activities, and concludes with a certain form of evaluation to demonstrate comprehension (Sweet, 2020, as cited in Cahapay, 2020). In modular distance learning, learners will receive modules collected weekly by the teacher. Parents must make a dropbox, also known as a learning package, in which the educator can store modules, and the parents can keep track of the learner's activities in this mode.

The second is Online Distance Learning, where it necessitates those learners to have access to the internet. In this mode, the teacher and student will connect virtually and perform their task either synchronously or asynchronously. Synchronous learning can take place online through classroom lessons, instant messaging, and online education, whereas asynchronous learning can occur via blog readings, documented videos, and dialogue boards (Lawless, 2020). Nevertheless, a recent investigation found that most students dislike online education (Hernando-Malipot, 2020). Lastly, there are Television and Radio-Based Instructions; these modalities of instruction are ideal for selfmotivated learners.

Blended learning is the second mode of instruction. It incorporates various techniques, including faceto-face instruction, online strategies, and technology (Graham, 2019, as cited in Tupas \& LinasLaguda, 2020). Additionally, it is a synthesis of constructivist and electronic teaching principles (Johnson, List-Ivankovic, Eboh, Ireland, Adams, Mowatt, \& Martindale, 2010). Due to its advantages in assisting a diverse student body, it is commonly referred to as "hybrid learning." It may not require internet access, and parents also must pick up teaching materials at the school. Ultimately, and maybe most significantly, there is the option of homeschooling. This method of instruction is efficient if the student has a mentor or a parent who is qualified and accessible always to assist the child's learning.

In accordance with that, this timely study explored the practices of secondary public school teachers in preparing for classroom observation amidst the new normal of education. It is believed that secondary public school teachers' practices in preparing the classroom observation in the new normal will encourage teachers to improve their teaching techniques, strategies, methods, and instructional materials to be used amid this pandemic.

\section{Research Questions}

This study was qualitative research that focused on exploring the practices of secondary public school teachers in preparing for classroom observation amidst the new normal of education. Its emphasis was drawn from the central question, "What are the practices of secondary public school teachers in preparing for classroom observation amidst the new normal of education?"

Specifically, it sought to answer the following queries:

1. What strategies, techniques, methods, and tools do the teachers use to prepare for classroom observation amidst the new normal of education? 
2. How do the teachers deliver their demonstration teaching for the new normal classroom observation?

3. What do the teachers think of how their new normal classroom observation tools are rated?

4. How important is the new normal classroom observation for the teachers?

5. What are the problems do the teachers encounter in preparing for classroom observation amidst the new normal of education?

\section{Literature review}

Teachers and students are being retrained and retooled to support schools' adoption of distance learning delivery modalities, according to the Department of Education (2021). Changes in the delivery of education influence the obligations and performance standards of teachers. Teachers' expectations must be documented in a more context-sensitive Results-based Performance Management System (RPMS).

As stipulated in DepEd Order No. 2, s. 2015, RPMS stands for the Results-based Performance Management System (RPMS). DepEd's vision, objective, values, and strategic goals are emphasized throughout the organization. It also manages, monitors, and measures teacher performance and organizational needs. The department wants to provide feedback on employees' progress and accomplishments and track their progress against goals to determine if any corrective actions are needed. Dizon, San Pedro, Munsayac, Padilla, and Pascual (2018) mentioned that DepEd strengthens its performance and responsibility culture while adhering to its overall organizational directive, vision, and mission by adopting the RPMS as its Strategic Performance Management System (SPMS). According to Department of Education (2015), corporate objectives and performance evaluation should be linked. Indicators are critical for monitoring individual performance and its effect on company goals.

In line with this, DepEd classroom observation in the new normal uses an instrument called the Classroom Observation Tool (COT) with three indicators: 1.) "Apply knowledge of content within and across curriculum teaching areas." 2.) "Plan and deliver teaching strategies that are responsive to the special educational needs of learners under challenging circumstances, including isolation, chronic illness, displacement due to armed conflict, urban resettlement or disasters, child abuse, and child labor practices." 3) "Select, develop, organize and use appropriate teaching and learning resources, including ICT, to address learning goals." The COT is an interactive platform that gives vital highlights and does not require complex inferences or judgments made by an observer. It is highly objective and specific and can be used to code observed behavior easily.

Classroom observation is a critical component of the RMPS because it delivers instructions and assesses learners' behavior. As the term suggests, learners observe behaviors and events recorded (Impoff, 2020). It employs various instruments to facilitate the effective collection of data. Some of the tools are also used in research, and they may include classroom observation schedules and stalling observation schedules. Through these instruments, educators can stimulate change and gather more valuable information while providing clear evidence and collecting data from naturalistic education settings. Accordingly, this improves education and enhances understanding. A classroom teacher invites a master teacher, head teacher, or the school head into their classroom to observe. Whether they are master teachers or beginning teachers, all the teachers involved could dialogue together and learn through a post-conference.

There are several relevant studies related to exploring the practices of secondary public school teachers in preparing for classroom observation amidst the new normal of education. Barrogo (2020) conducted one of these pertinent studies, analyzing teachers' attitudes toward the standardized classroom observation tool. The researcher used a descriptive design in this study, with a survey as the primary instrument for data collection. The findings indicated that a single standardized classroom observation tool could be used to assist teachers in evaluating their performance and providing an improvement plan, thereby continuing to improve teachers' preparation and competency. 
Castillo (2021) conducted a qualitative study to understand junior high school teachers' perceptions and experiences of conducting class observation during the COVID-19 pandemic in 2020-2021. The study did identify remarkable perceptions of junior high school educators regarding the importance of conducting the class observation. A phenomenological research design is used in conjunction with an accommodating interview with 15 teachers as study informants. The study found that instructional leaders and teachers could coordinate and plan class observation tasks to benefit both parties.

Meanwhile, Garcia, Narca, Mariano, and Fronda (2020) determined the extent of teaching standards expertise of Senior High School-Accountancy, Business, and Management (ABM) teachers by utilizing the Classroom Observation Tool (COT). The study also examined the relationship between significant differences in teachers' performance levels based on their profile variables. However, the result proved that profile variables and grade level taught to have no significant difference in performance.

Cabigao (2021) portrayed a teacher-approachable class observation post-conference structure based on Carl Rogers' Self Theory, which emphasizes a person-centered approach, with the self as the central focus of personality research. The framework begins with teachers sharing personal lived experiences as conscious awareness during their teaching presentation. Educators are entitled to discuss themselves in a welcoming and approachable environment to instill a positive atmosphere for the duration of the post-conference portion of the classroom observation.

Wairimu (2016) also investigated teachers' perceptions of head teachers' classroom observation practices in Nakuru North district government elementary schools. Classroom observation and the head teacher checking students' workbooks were examined in relative to educators' perceptions of duty performance. The research design was a descriptive survey. The study surveyed twenty school administrators and ninety-four teachers. According to the research, school leaders visit classrooms and convene conferences to resolve conflicts. Audits of teachers' professional documents were conducted to ascertain the amount of work completed and the comments made by the majority of school leaders. Teachers agreed that instructional supervision enhances teaching and learning and that head teachers manage classrooms, which they viewed positively.

Moreover, by utilizing classroom observation tools throughout the teaching practice, an individual's behavior is enriched cumulatively. As a result, knowledge about the new behavior influences the actual rate of learning. Indeed, the teacher's comprehension learning process accelerates slightly, resulting in enhanced behavioral changes. Education World (2021) stated that teacher classroom observation would be included in the pool of opportunities for professional development. However, new online or other distance learning protocols require teachers to change their daily tasks, responsibilities, and accountability quickly. During the COVID crisis, educators may be needed to create new formative or summative methods for monitoring students' development. Additionally, De Villa and Manalo (2020) performed a relevant study to examine the secondary teachers' lived experiences before the New Normal implemented distance learning. Specifically, it sought to ascertain (1) teachers' preparation for the new normal of education, (2) the obstacles they face as they prepare for distance learning, and (3) their coping mechanisms for overcoming those obstacles. The findings indicated that educators make vital arrangements to embrace distance learning as education changes to a new normal. While they face obstacles that may impair their job, they can adapt to the new normal and complete their responsibilities. Before implementing distance learning, school authorities should collaborate with teachers to address their resource and training needs to deliver quality education.

Following this, Arrieta, Dancel, and Agbisit (2020) examined and comprehended junior high school science teachers' difficulties and perspectives following another term or nearly three months of continuing education in the new normal. The investigation discovered that science teachers had been equipped and the curriculum had been altered. The instructional materials were strengthened, and numerous obstacles such as student behavior, task distribution and operation, a limited amount of time for competency integration, and student participation were overcome. 
Another study, Butron (2021) evaluated teachers' responsiveness, emotional reactions, and activities to ascertain the level of support they require at home to perform the task and responsibilities efficiently and effectively in the new normal of education. Educators report completing daily tasks, according to the findings. Despite working from home, teachers maintain a connection to the school, and their primary responsibility under the new educational standard is to evaluate participants' progress.

Also, Joshi, Vinay, M., and Bhaskar (2020) analyzed the strategies used by higher education institutions to continue imparting education during a lockdown. Additionally, the study discusses the difficulties that teachers face when teaching online from their homes. The outcomes indicated that higher education institutions (HEIs) had held numerous programs to impart education in this pandemic situation. However, from the teacher's perspective, these initiatives have been a failure. Teachers face various challenges when teaching online, including a lack of technical resources, interruptions from family, a lack of training, clarity, direction, and a lack of knowledge.

Furthermore, Ali and Kaur (2020) assessed how teachers coped with online learning after nationwide school closures. They used a meta-synthesis methodology and cited relevant literature to understand the essence of continuous learning during these unexpected times. The findings indicate that teachers were gradually adopting aspects of online learning. Similarly, Barrera, Jaminal, and Arcilla (2020) surveyed their students and teachers regarding readiness to flexible learning in the new normal of education. The results discovered that teachers should be trained in online teaching, and the education system should be revised to cater to the paradigm shift.

\section{Research methodology \\ Research design}

This study used a qualitative research design. It employed a phenomenology design to explore the practices of secondary public school teachers in preparing the new normal classroom observation. Phenomenology was used because it centers on the lived experiences of the secondary public school teachers on their encounter with the new normal classroom observation.

\section{Participants of the Study}

The sources of data were the two secondary public school teachers in Cagayan, Philippines. These public national high schools have Junior and Senior High Programs offering the general education curriculum and the SHS curriculum mandated by the Department of Education. Purposive sampling was used with the following distribution for each of the schools:

Table 1. Distribution of Respondents

\begin{tabular}{cccc}
$\begin{array}{c}\text { Position and } \\
\text { Department }\end{array}$ & Public School 1 & Public School 2 & Total \\
\hline Teacher -I (JHS) & 2 & 2 & 4 \\
Teacher -II (JHS) & 0 & 2 & 2 \\
Teacher -III (JHS) & 3 & 2 & 5 \\
Master Teacher (JHS) & 1 & 2 & 3 \\
Teacher -I (SHS) & 1 & 0 & 1 \\
Teacher -II (SHS) & 3 & 3 & 6 \\
Teacher-III (SHS) & 1 & 0 & 1 \\
\hline TOTAL & 11 & 11 & 22
\end{tabular}

\section{Instrumentation}

A formal written communication addressed to the school heads contained the request for approval to conduct the research. When communication was approved, the researchers through the channel asked permission from both schools' junior and senior high school coordinators to collect the data. The interview protocols were self-administered to fully consented participants from the two schools using Google Meet. 
All responses from the two secondary schools were automatically recorded in the database and checked initially to verify missing and incorrect inputs. Since the researchers utilized Google Meet in collecting the data in the study, they have undergone recoding with the consent of the participants to ensure that data needed are appropriately categorized. The study results were communicated in generic form to all participants, other than acknowledging their participation. General recommendations were stated, and directions were proposed.

The instrument used in gathering data for this research was mainly an interview protocol which composed of two sections, including (1) the Profile and (2) the Practices of the Participants as what methods, strategies, techniques, instructional materials, and evaluation system used in preparing the new normal classroom observation

\section{Analysis of data}

The qualitative data collected was analyzed using content analysis in thematic manner, a qualitative descriptive approach wherein data is quantified in content analysis. In contrast to the tradition of quantitative data analysis, it does not imply that phrases and concepts are transformed into numerical values for data analysis purposes. In some cases, however, it may mean that the repetition of the same or comparable codes in the transcription is deemed necessary for developing a category or for organizing the theme's structure. It is anticipated that the underlying codes will influence the significance of the theme in the given data. Something significant regarding the research question will be captured as a result. It was decided to use this method of data analysis because the researchers wanted to collect information that showed that a specific narrative element was repeated across all of the responses they received.

\section{Results and discussions}

After conducting a qualitative analysis of the responses from the 22 participants, four major themes emerged from the data. Each theme has corresponding sub-themes that were culled from the subsequent thematic analysis.
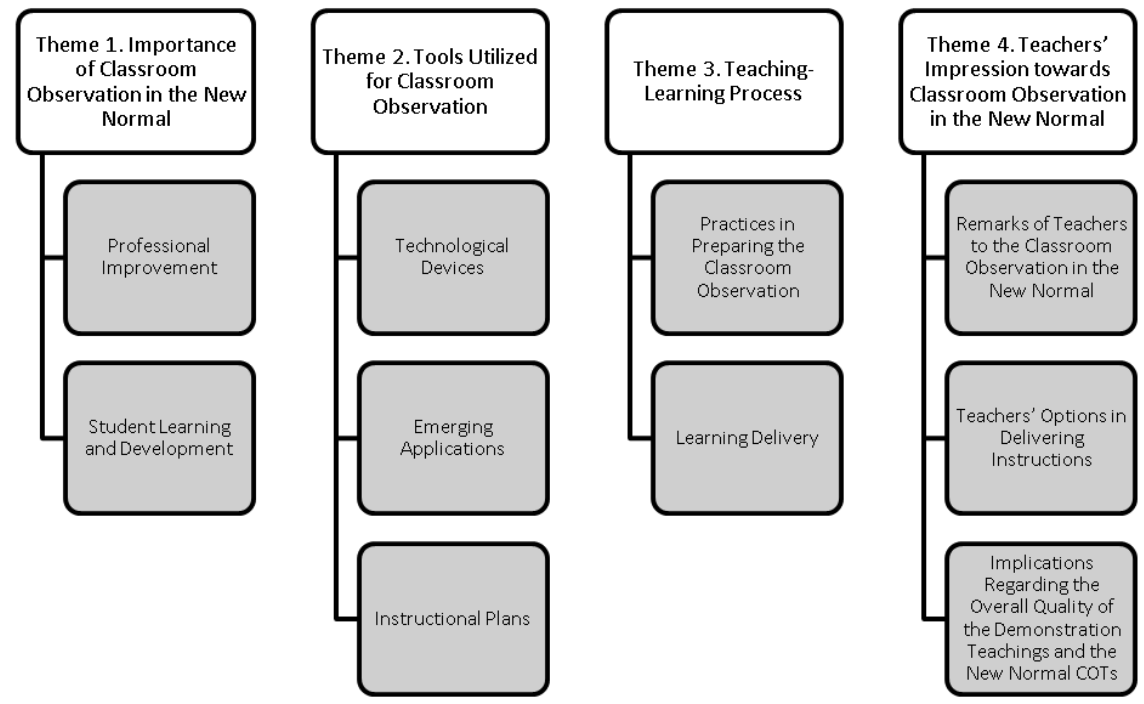

Figure 1. Themes and sub-themes

\section{Theme 1. Importance of classroom observation in the new normal}

Two sub-themes were identified by the researchers from the responses of the participants. The importance of classroom observation in the new normal was categorized into (1) Professional Improvement and (2) Student Learning and Development. 


\section{Professional improvement}

Participants 2, 3, 11, 12, and 18 stated, "Classroom observation is a way to improve teaching skills and teacher quality." They also mentioned, "It is another way for us to identify various tasks that the teacher can perform and its development needs. A classroom observation is beneficial for identifying those who require more assistance.". In addition, they said, "It is a basis in planning an in-service training for teachers."

In addition, Participants 4, 5, 7, 9, 10, 13, 14, and 22 said, "It is useful to assess the teachers' performance and evaluate the teachers' strengths and weaknesses in the teaching-learning process in the new normal." They also added, "It serves as one of the measuring tools in achieving your teacher/professional goals or performance level of a teacher. It may not measure all, but it will help us in becoming better educators."

Moreover, Participants 15, 16, and 17 stated, "It helps me perform well and makes me grow professionally. It is essential because it keeps me on track." A teacher's observations in the classroom lead to improved teaching practices, especially this trying times. It is also a useful strategy that teachers can employ to assist them in improving their classroom management skills.

Halim, Wahid, and Halim (2018) stated in their study that classroom observation promotes interaction among coworkers to enhance teacher instruction and student learning. Classroom observation feedback is an efficient strategy of informing teachers about their school environment and supporting their ongoing professional development.

\section{Student learning and development}

Participants 1, 2, 10, 12, and 21 said, "It is used to deliver quality education to the learners. It is a tool that helps teachers reflect on their performance to enhance the teaching methods and strategies to be utilized in teaching the learners in the new normal." They mentioned, too, "It is a way to effectively and efficiently evaluate and assess the students' learning outcomes." Teacher observation is a valuable tool for professional growth and, as a result, for improving student outcomes. It also enhances the teacher's teaching abilities, becoming a more effective and efficient public school teacher.

According to Pecoraro (2020), having access to a high-quality education enables students to understand their school subjects better. It will improve their motivation to learn, which will result in improved performance in class. Additionally, he stated that students would gain more understanding and knowledge using effective learning practices. It will prepare them to be self-sufficient in any condition, both inside and outside of school.

\section{Theme 2. Tools utilized in classroom observation}

Three sub-themes were identified by the researchers from the responses of the participants. The tools utilized for classroom observation were categorized into: (1) Technological Devices, (2) Emerging Applications, and (3) Instructional Plans.

Technological devices

Participants 3, 14, 15, 18, and 19 stated, "Laptop or smartphones/android phones and internet access are the basic devices needed in doing the classroom observation in the new normal." They also added, "Smart TV, if available, is also suggested to be used for a wider screen viewing." In addition, they also said that "Using ring light will make the video presentation more effective and clearer for viewing."

Due to the rapid growth in communication technology users, new technologies and education are required to develop new student learning activities. In this pandemic, information technologies devices can help students access study classes, interact with or converse with instructors, and ask other students queries. 
Friyanto, Prasetyo, and Albar (2020), in their study, "Technology-based education," reported that Learners were incredibly supportive of the use of smartphones and computers to obtain lectures and education, based on the current survey which was conducted by the Educause Center for Applied Research (ECAR). According to a university survey, 67 percent of the students agreed that technology is critical for academic activities in classroom instruction.

Hence, more excellent technology capabilities are improved leverage in the teaching process, and both old and contemporary techniques impact learning results. It is essential to the curriculum's effectiveness that it is kept up to date by incorporating newly created technology tools and equipment.

Emerging applications

Participants 12, 16, 17, 19, and 22 said, "Filmora, Kinemaster, Power Director, and VivaCut are highly recommended for video editing software."

While fighting this pandemic, video lessons have developed, with most teachers noticing an improvement in remote instruction. Based on ONVU Learning (2021), when video lessons are used in classrooms, they significantly impact the student because teachers can evaluate their lessons without face-to-face contact. The idea of sharing recordings with even more than one colleague or student enables more discussion about the most effective methods for teaching specific topics or classes.

In addition, Participants 1, 8, 10, and 20 stated, "Interactive games were also employed in the video lesson presentation." As reported in the study of Lieberman (2006), utilizing games to enhance the learning process is highly effective. It was discovered that people gain knowledge when asked to think, explore, and respond in games. Frequently, games require learners to solve complex problems. They interact with the team environment, develop their abilities, and practice their abilities. Additionally, they have the freedom to attempt and fail before succeeding and receiving support. Learners adapt to game difficulties, ensuring that they remain challenging but not excessively difficult.

Meanwhile, Participants 1, 4, 8, 10, and 11 said, "As a 21st-century educator, I utilized different online educational platforms such as Google Meet, Google Form, and Google Classroom in teaching. I would maximize the use of online educational technologies. I used Google Meet, Kahoot, and Quizziz for the assessment and PowerPoint in discussion and video clips to motivate my learners as an add-on. As a teacher-innovator, I incorporated interactive platforms and games into my work. Several educators who've been a completely remote struggle to strike a balance between instructional pedagogy and engagement. Additionally, I facilitated discussions and teamwork and ensured that time was set aside for socioemotional learning. I always make an effort to be accessible and adaptable."

During this new normal of education, the utilization of information and communication technology (ICT) facilitates cooperation. Bringing students together to discuss and debate their work aids in communication skills. ICT motivates learning as society's demand for new technology has not forgotten about learners and their needs. Technology is both inspiring and encouraging to learners in the classroom.

ICT improves student engagement and effective learning. Learners become more engaged in their work when ICT is incorporated into lessons. Technology allows new ways to make learning more fun and enjoyable by teaching novel concepts. As a result of this increased engagement, they will be able to maintain knowledge more effectively and efficiently (ICTE Solutions, 2020).

Besides, Participants 5, 14, 15, 16, 17, 18, 21, and 22 shared that "The module was supplemented with video material. By using cloud computing like Google Drive, I delivered or sent recorded video lessons online. I recorded a video lesson. I utilized the different applications in video presentation wherein the teacher is speaking to the camera, and photographs were also added. Through the video lesson, the topic has been explained clearly. I also attended webinars on different video editing tools and software. Learning more about video editing is one of the strategies I used in preparing the New 


\section{Normal Classroom Evaluation."}

Nowadays, both sides of the classroom can benefit from the use of video learning. Video lessons, once completed, can be reused and updated to save time at the school for live discussions and student engagements.

EdSurge (2020), in his essay "The Importance of Videos for Teaching and Learning," mentioned that In studies, video learning had been shown to have positive effects on a variety of levels, including greater productivity and comprehensible input, as well as the ability of the students to enable discussions and address problems on their own. EdSurge (2020) also mentioned that video allows both the learner and the educator to interact one-on-one without ever being in the same room together. Teachers in general and special education can benefit from video training because it allows them to teach the students at their own pace, which helps close the training gap. Multiple viewings of a video are recommended for students to gain and keep learning material. Captions, for example, make it possible for deaf students to follow along with the video.

\section{Instructional plans}

According to Participants 2, 11, and 13, "Daily lesson log or individual workweek plan is still essential in conducting a classroom observation in the new normal. I still used the lesson plan as a guide. I am drafting my lesson plan first before drafting my script." A teacher with a plan is a more confident teacher, according to Jensen (2001). They know what to do when and how. Everything has been gathered and decided upon beforehand, so the lesson will run more smoothly. The teacher will not end up wasting class time flipping through the workbook or making photocopies. A confident teacher will inspire more compassion from students, reduce discipline issues, and make them more open to learning.

Participants 1 and 13 mentioned that "I still used 4As Lesson Plan as a format in preparing my lesson. My approach in my lesson is 4As, the Activity, Analysis, Abstraction, and Application." Even in this educational crisis, educators must plan their lessons daily or weekly in advance and employ the most effective teaching methods. Attending classes without a study guide has a negative effect on both teachers and students. When an educator is not adequately prepared, they project an image of incompetence and unprofessionalism to their colleagues, administrative staff, and students. (Impoff, 2020). Collaboration between students and teachers is essential in promoting quality and creative learning experiences, and the 4As may be one of the most helpful features in this endeavor. Kolb's Experiential Learning Theory is the foundation of this approach, which aims to approach the child as a whole. It also recognizes the student's previous schemes. It integrates them into a new one, so this structure will likely bring out what was stored and that what has been missing would be filled in eventually, leading to a more in-depth understanding of the lesson content.

On the other hand, Participants 4, 6, 7, 9, and 11 said, "Classroom Observation Tool in the new normal is still important as a guide during the observation process." According to Department of Education (2021), for SY 2020-2021, the adjustments to RPMS, its tools, procedures, and protocols reflect the current system in place at the Department of Education to govern teachers' functions. The chosen RPMS objectives are intended to assist teachers in adapting and responding more rapidly and effectively to developing circumstances linked with the pandemic's challenges.

Moreover, Participants 4 and 11 mentioned, "Aside from the Classroom Observation Tool as a guide, Performance Monitoring Plan and Observation Note are also needed in conducting classroom observation in the new normal." Observation is an effective means of observing a teacher's progress. When utilized correctly, it also supports teachers by providing a comprehensive picture, and thus specific objectives can be set. Providing feedback is a complex skill, which needs to be learned and honed. Monitoring aims to track, identify, and improve project implementation to meet project goals and objectives. Continuous observation, structured documentation, as well as critical reflection are all part of monitoring. 
Theme 3. Teaching-learning process

The teaching-learning process was categorized into (1) Practices in Preparing the Classroom Observation and (2) Learning Delivery.

Practices in preparing the classroom observation

According to Participants 6 and 10, "Upon preparing my lesson, I consider the different learning styles of my learners. In my subject, I utilized a team-based learning approach, a group collaboration teaching practice used to engage students' knowledge."

Several research results show that student learning styles are highly dependent on the teaching methods employed by the teacher. For different learning styles, these teaching methods are ineffective. In other words, the most effective learning method for students proved to be less effective for students with different learning styles.

Students' preferred learning styles can encourage them to reflect on their preferred methods of instruction, giving them a greater sense of belonging and control over their education. Learning styles serve as a reminder that each student is unique. Finally, they can increase teachers' enjoyment of teaching and help them develop their professional skills (Colors-NewYork, 2019). Additionally, cooperative learning can effectively motivate students, promote active learning, and develop students' critical reasoning, interaction, and decision-making skills. On the other hand, if teamwork is not properly planned and facilitated, it can be frustrating for both students and instructors.

In addition, Participants 14 and 21 shared that "I applied various tools and strategies to deliver the lesson, such as integrating online interactive games with the learners to gain interest in the topic. I gave a formative assessment to every end of the topic to assess their learning. Online quizzes were utilized. Before you start, it is important to know your capabilities in terms of ICT skills. Also, you must still find ways on how your video lesson to be more appealing and interactive to the learners."

ICT could indeed improve the value of education in various aspects, including by enhancing student motivation and engagement, enabling the acquisition of core concepts, and improving teacher instruction, among other things. When used appropriately, ICTs are transformative tools that can facilitate the transition to a learner-centered environment (Life Learners Academy 2018). New normal education through ICT can enable teachers and students, facilitate change, and promote 21 st-century competencies. It can allow teachers and students to shift the focus of teaching and learning processes from focusing on the teacher to the students. It will increase students' learning gains by encouraging and developing their resourcefulness, problem-solving abilities, and informational reasoning skills.

Learning delivery

Participants 1, 5, and 16 mentioned that "In terms of learning delivery, it is the same as I have during the Face-Face. I start it with motivation, discussion, and activities. It starts with introducing the teacher, checking previous activities, reviewing past lessons, discussing the new lesson, and reinforcing activities. I made sure that my lesson plan was well crafted."

A well-prepared teacher is well on their way to providing their students with a successful instructional experience. Developing engaging lessons takes a significant amount of time and effort. To succeed as a new teacher, you must be willing to put in the necessary effort. When lessons are delivered effectively, students' comprehension increases, resulting in increased student participation and an overall increase in the quality of student work.

Additionally, it is crucial to recognize that even the most carefully planned lesson will be ineffective without engaging delivery procedures and classroom discipline techniques. All teachers should acknowledge that they are not self-contained islands. The district's educational philosophy and uniqueness should serve as the guiding force for the classroom. Every teacher's classroom management effort must reflect the school's code of discipline that should be fair, responsible, and meaningful (Kean Universit, 2019). 


\section{Theme 4. Teachers' impression towards classroom observation in the new normal}

The impression of teachers towards classroom observation in the new normal was categorized in the following: (1) Remarks of Teachers to the Classroom Observation in the New Normal, (2) Teachers' Options in Delivering Instructions, and (3) Implications Regarding the Overall Quality of the Demonstration Teachings and the New Normal COTs.

Remarks of teachers to the classroom observation in the new normal

Participants 1, 2, 4, and 9 stated that "I think that the new classroom observation is a unique experience and challenge for teachers. Classroom observation serves as our guide in assessing ourselves and planning for the following year's activities. It is effective because teachers with so much passion prepare it." Moreover, Participants 10 and 25 stated that "Performance evaluation will improve the teaching process of teachers. Thus, learners will be benefited because their teachers are improving when it comes to their teaching process despite pandemic. The formulated evaluation system is suited to the needs of the teachers who are in distance learning gear. It is still appropriate to conduct performance evaluation."

Currently, observation is a reliable means for assessing and observing a teacher's progress as they learn their craft. Because observation provides such a comprehensive picture and allows for establishing particular objectives, it can also be used to assist teachers if done correctly. Observation and criticism are highly multifaceted skills that require extensive training and practice to master appropriately.

As Halim et al. (2018) mentioned in their study, it is critical to observe classroom activities to make the teaching-learning process more visible. In order to assist teachers in improving their effectiveness in the classroom, this program provides them with constructive and critical feedback on their effective teaching and teaching methods. Education professionals must pay close attention to the interactions between teachers and students in the classroom because these interactions can impact the learning prospects available to students.

Teachers' options in delivering instructions

According to Participants 5, 8, 15, and 19, "I prefer a video lesson. It starts with introducing the teacher, checking previous activities, reviewing past lessons, discussing the new lesson, and reinforcing activities. Observation of a video lesson- easy to access anytime, easy to deliver, and use in many ways. Observation of a video lesson is easier to prepare than the other option, and it does not require an internet connection. I prefer observing a video lesson because I can edit the video to remove mistakes before having it rated."

Students can access video lessons from any location by using their laptops, tablets, or smartphones. Learners take pleasure in the learning process at their own pace. Video lectures can be uploaded to YouTube and then shared with students via a link.

Video lectures are a well-known method of distance learning. However, they can be incorporated into one's classroom instruction. Such a novel educational approach will engage students and inspire colleagues. Additionally, during interactive video lectures, people can access additional valuable resources and materials for self-study. Additionally, you can record another lecture to supplement the class activities. (ISpring, 2021).

Implications regarding the overall quality of the demonstration teachings and the new normal COTs As mentioned by Participants 17, 20, 21, and 22, "Classroom observation can be done maybe just once to package the whole performance of the teacher in a year. For the teachers to be observed, this is, shall I say, another burden because instead of focusing on his subject matter, they will prepare all year round for his classroom observation. Before we can easily assess the students after the lesson's discussion, we cannot do it immediately because there is no interaction between them. Before, there are many criteria to assess the teacher's performance level, but it is simpler and less criterion today. 
Performance evaluation is suited to our present situation and helped our learners amidst the crisis. It is not easy to evaluate teachers online as to their effort and readiness while teaching. DepEd finds means and ways to address teachers teaching problems. Observation via video lesson because it is where I am most comfortable. I am happy and contented with my rating. It is a good and reliable tool. Before, the rater evaluates teachers' performance. Unlike in the new normal, the rater hardly evaluates actual performance because everything is based on videos. The number of COT was indeed reduced to half, but the preparation for the two COTs is more challenging. It will pave the way for the school administration and the whole department and the needs of teachers' improvement in terms of delivering quality education without face to face. Classroom observation is much harder compared to before. I realized the importance of having the learners in face-to-face classroom observation to assess the teachers' performance."

To ensure that educators are prepared for the new normal classroom observation, both teachers and observers agreed on some predetermined indicators prior to the observation taking place. Another study discovered that an effective supervision process entails three steps: planning for observation, conducting observation, and tracking the observation results post-observation. Classroom observation is the process of sitting in on another teacher's class and observing, learning, and expressing what is going on. Additionally, a classroom observation is described as evaluating and documenting specific details about what occurs in a classroom setting. Teachers are frequently exposed to innovative teaching methods that they were unaware of throughout the classroom observation process prior to the observation. As a result, observation is essential throughout a teacher's professional life and career. The further problem is that many educators, even the most experienced ones, seem to be utterly ignorant about the nature of their interconnections with individual students. One of the main objectives of classroom observation was to assist teachers in improving the quality of their instruction in the classroom. Teachers can develop a greater understanding of how their classroom operates by conducting reviews and implementing desired changes. Additionally, teachers are aware of their strengths and weaknesses and constantly look to improve their instruction (Halim et al., 2018).

\section{Conclusion}

With the preceding findings, the researchers concluded the following: first, observing classrooms is a way to improve teaching skills and teacher quality. It is another way to identify different tasks that the teacher can perform and their development needs. It also helps identify those who need help getting the extra training they need to be effective. Classroom observation in the new normal is a tool that enables teachers to reflect on their performance to improve the methods and strategies used to teach learners this time of the pandemic. Second, this pandemic, a laptop or smartphone or android phone, and internet access, are the primary devices required for conducting classroom observations in the new normal. Another, in preparing a video lesson, video editing software such as Filmora, KineMaster, Power Director, and VivaCut are highly recommended by teachers. Keeping a daily lesson log or creating an individual workweek plan is still necessary for classroom observation in the new normal. They also integrate 4As teaching approach and information and communications technology (ICT) in their class to assist their interactions with students. Also, teachers are constantly checking the learning styles of their learners to incorporate best practice strategies into their activities, curriculum, and assessment procedures. They make sure lessons are meaningful, and their lessons are well crafted. Finally, when teachers observe a classroom for the first time, they encounter a novel and challenging experience. They will benefit from improved teaching processes because of performance evaluation. As a necessary consequence, learners will benefit as their teachers improve their teaching abilities in the face of the pandemic. Additionally, they prefer video lessons because they are convenient, deliver, and utilize in various ways. Video lessons are more accessible to prepare than other types of lessons. A classroom observation is defined for teachers as the process of evaluating and documenting detailed information about a classroom. Classroom observation frequently aids in their exposure to novel teaching techniques that may not have occurred previously.

\section{Recommendation}

With the conclusions drawn, the researchers recommended the following: 
1. Class observers, such as the school head and master teachers, should be adequately trained to provide the most effective supervisory observations and guidance.

2. Schools should have a follow-up intervention that will focus on improving the teachinglearning process. Discussions about the latest RMPS standards, video editing, and photo editing should be part of the in-service training for educators.

3. Teachers should be given additional load and internet allowance for online classes. Teacher software licenses, such as Adobe Cloud and Filmora, should be provided by the Department of Education to all teachers.

4. Webinars regarding the different teaching techniques and strategies on conducting classes this time of new normal should be initiated by the school every quarter for continuing education of teachers.

5. Future researchers may conduct a comparative study on the implementation of the RPMS before and during this new normal.

\section{Limitation and study forward}

This study is limited to 22 secondary public school teachers in Cagayan, Philippines.

\section{References}

Adnan, M., \& Anwar, K. (2020). Online learning amid the COVID-19 pandemic: Students perspectives. Journal of Pedagogical Sociology and Psychology, 1(2), 45-51. https://doi.org/10.33902/jpsp.2020261309

Ali, W., \& Kaur, M. (2020). Mediating educational challenges amidst covid-19 pandemic. Asia Pacific Institute of Advanced Research, 6(2), 40-57. https://apiar.org.au/wpcontent/uploads/2020/08/4_APJCECT_V6_I2_2020_pp.40-57.pdf

Arrieta, G. S., Dancel, J. C., \& Agbisit, M. P. (2020). Teaching Science in The New Normal: Understanding The Experiences of Junior High School Science Teachers. Jurnal Pendidikan MIPA, 21(2), 146-162. http://jurnal.fkip.unila.ac.id/index.php/jpmipa/article/view/21460

Barrera, K. I., Jaminal, B., \& Arcilla, F. J. (2020). Readiness for flexible learning amidst COVID 19 pandemic of Saint Michael college of Caraga, Philippines. SMCC Higher Education Research Journal, 2(1). https://doi.org/10.18868/cte.02.060120.01

Barrogo, S.D. (2020). Teachers' Perception of Standardized Classroom Observation Tool. International Journal of Academic Pedagogical Research (IJAPR), 4(7), 15. https://dx.doi.org/10.13140/RG.2.2.16123.13603

Butron, V. (2021). Responsiveness, Emotions, and Tasks of Teachers in the New Normal of Education in the Philippines. International Journal of Research Publication and Reviews, 2(4), 310-315. https://www.ijrpr.com/uploads/V2ISSUE4/IJRPR378.pdf

Cabigao, J. R. (2021). Class Observation Post-Conference Framework for Teachers. International Journal of Academic Multidisciplinary Research, 5(2), 256-258. https://www.researchgate.net/publication/349692651_Class_Observation_Post-

Conference_Framework_for_Teachers

Cahapay, M. B. (2020). Philippine basic education learning continuity plan: Creating space for Indigenous Peoples toward inclusive post-COVID-19 education. International Journal of Pedagogical Development and Lifelong Learning, 2(1), ep2102. https://www.researchgate.net/publication/346474579_Philippine_Basic_Education_Learning_ Continuity_Plan_Creating_Space_for_Indigenous_Peoples_toward_Inclusive_post-COVID19_Education

Castillo, E. C. (2021). Adjusting to the New Normal Education: Perceptions and Experiences of Fellow Junior High School Teachers on the Conduct of Class Observation this COVID-19 Pandemic. International Journal of Academic Multidisciplinary Research, 5(4), 41-44. https://www.researchgate.net/profile/Eleanor-Castillo-

2/publication/350515482_Adjusting_to_the_New_Normal_Education_Perceptions_and_Expe riences_of_Fellow_Junior_High_School_Teachers_on_the_Conduct_of_Class_Observation_t his_COVID-19_Pandemic/ 
Colors-NewYork. (2019). How do school buildings affect learning? Colors-NewYork.com Reconstructing the story of humanity's past. https://colors-newyork.com/how-do-schoolbuildings-affect-learning/

Department of Education. (2021). [DM-PHROD-2021-0010] guidelines on the implementation of RPMS for SY2020-2021_signed.pdf. Google Docs. https://drive.google.com/file/d/1wm6qwntEPMqP-5ZWjk1CrkZMmZbLbkj4/view

Department of Education. (2021). RM-s2021-024 - DepEd Region VIII. DepEd Region VIII. https://region8.deped.gov.ph/wp-content/uploads/2021/01/RM-s2021-024.pdf

Department of Education. (2020, July 22). Ano ang pwedeng learning delivery modality? https://www.deped.gov.ph/2020/07/22/ano-ang-pwedeng-learning-delivery-modality/

Department of Education. (2015, February 6). February 6, 2015 DO 2, S. 2015 - Guidelines on the establishment and implementation of the results-based performance management system (RPMS) in the Department of Education. https://www.deped.gov.ph/2015/02/06/do-2-s-2015guidelines-on-the-establishment-and-implementation-of-the-results-based-performancemanagement-system-rpms-in-the-department-of-education/

De Villa, J., \& Manalo, F. K. (2020). Secondary teachers' preparation, challenges, and Coping mechanism in the pre-implementation of Distance learning in the new normal. IOER International Multidisciplinary Research Journal, 2(3), 1-11. https://www.researchgate.net/profile/Franz-

Manalo/publication/344599746_Secondary_Teachers'_Preparation_Challenges_and_Coping_ Mechanism_in_the_Pre_-

Implementation_of_Distance_Learning_in_the_New_Normal/links/5f836d9d299bf1b53e20bc 8d/Secondary-Teachers-Preparation-Challenges-and-Coping-Mechanism-in-the-PreImplementation-of-Distance-Learning-in-the-New-Normal.pdf

Dizon, A. D., San Pedro, A. B., Munsayac, M. M., Padilla, J., \& Pascual, M. C. (2018). Level of implementation of the results-based performance management system in the Department of Education division of gapan city, Philippines. International Journal of Research GRANTHAALAYAH, 6(1), 484-503. https://doi.org/10.29121/granthaalayah.v6.i1.2018.1658

EdSurge. (2019, October 2). The importance of videos for teaching and learning. Giving Compass. https://givingcompass.org/article/the-importance-of-videos-for-teaching-and-learning/

Friyanto, A., Prasetyo, I., \& Albar, C. N. (2020). Technology-based education. Journal of Physics: Conference Series, 1764 (2021) 012193. https://iopscience.iop.org/article/10.1088/17426596/1764/1/012193/pdf

Garcia, R. E., Narca, J. A., Narca, J. A., Mariano, L. K., \& Fronda, J. G. (2020). Analysis of senior high school -accountancy, business and management Strand teachers performance. International Journal of Research -GRANTHAALAYAH, 8(1), 131-137. https://doi.org/10.29121/granthaalayah.v8.i1.2020.260

Graham, C. R. "Current Research in Blended Learning." In M. G. Moore and W. C. Diehl (Eds), Handbooks of Distance Learning (4th, 2019, pp. 173-188). New York NY: Routledge.

Griffiths, B. (2016). A Faculty's Approach to Distance Learning Standardization. Teaching and Learning in Nursing, 11(4), 157-162. https://doi.org/10.1016/j.teln.2016.04.004

Guo, Y., Cao, Q., Hong, Z., Tan, Y., Chen, S., Jin, H., Tan, K., Wang, D., \& Yan, Y. (2020). The origin, transmission and clinical therapies on coronavirus disease 2019 (COVID-19) outbreak - an update on the status. Military Medical Research, 7(1). https://doi.org/10.1186/s40779020-00240-0

Halim, S., Wahid, R.A., \& Halim, T. (2018). Classroom observation- A powerful tool for continuous professional development (Cpd). International Journal on Language, Research and Education Studies, 2(2), 162-168. https://doi.org/10.30575/2017/ijlres-2018050801

Hernando-Malipot. (2020, July 3). DepEd: Most students prefer 'modular' learning over online. Manila Bulletin. https://mb.com.ph/2020/07/03/deped-most-students-prefer-modular-learningover-online/

Impoff. (2020, November 20). Importance of lesson plan and effective lesson planning. IMPOFF. https://impoff.com/importance-of-lesson-plan/IvyPanda. (2019, June 3). Classroom observation theory - 852 words | Research paper example. Free Essays. https://ivypanda.com/essays/classroom-observation-theory/ 
Johnson, N., List-Ivankovic, J., Eboh, W., Ireland, J., Adams, D., Mowatt, E., \& Martindale, S. (2010). Research and evidence based practice: Using a blended approach to teaching and learning in undergraduate nurse education. Nurse Education in Practice, 10(1), 43-47. https://doi.org/10.1016/j.nepr.2009.03.012

Joshi, A., Vinay, M., \& Bhaskar, P. (2020). Online Teaching amidst COVID-19 in India: An Outlook. Asian Journal of Distance Education, 15(2), 10511. http://www.asianjde.com/ojs/index.php/AsianJDE/article/view/454

Kaur, G. (2020). Digital Life: Boon or bane in teaching sector on COVID-19. CLIO an Annual Interdisciplinary Journal of History, 6(6), 416-427

Kean University. (2021). Effective lesson planning, delivery techniques. Kean University. https://www.kean.edu/ tpc/Classroom\%20Management/EFFECTIVE\%20LESSON\%20PLA NNING\%20\&\%20Classroom\%20Mgmt.htm

Lawless, C. (2020, November 12). Synchronous vs asynchronous learning: Which is right for your learners? LearnUpon. https://www.learnupon.com/blog/synchronous-learning-asynchronouslearning/

Lieberman. (2006, July 14). What can we learn from playing interactive games? ResearchGate. https://www.researchgate.net/publication/285448990_What_Can_We_Learn_From_Playing_I nteractive_Games

Life Learners Academy. (2018, June 19). The importance of ict in education. Life Learners Limited. https://lifelearners.ng/the-importance-of-ict-in-education/

ONVU Learning. (2021, March 16). What will lesson observation look like in the new normal? ONVULearning. https://www.onvulearning.com/blogs/lesson-observation-in-the-new-normal

Pecoraro. (2020, November 12). 6 benefits of quality education for students. Student Caring - Helping Parents, Professors and Their College Students Achieve Success. https://www.studentcaring.com/6-benefits-quality-education-students/

Sweet, K. (2020). What is an educational module? Classroom. https://classroom.synonym.com/whateducational-module-4739884.html

Education World. (2021). Teachers observing teachers: A professional development tool for every school. Education World | Connecting educators to what works. https://www.educationworld.com/a_admin/admin/admin297.shtml The importance of videos for teaching and learning. (2019, October 2). Giving Compass. https://givingcompass.org/article/the-importance-of-videos-for-teaching-and-learning/

ICTE Solutions. (2020). The |Importance of ICT in Education|. https://www.ictesolutions.com.au/blog/why-schools-should-invest-in-ict/ The importance of project monitoring. (2020, February 17).

ISpring. (2021). Top 8 advantages of using video presentations in teaching. eLearning Software: LMS and Authoring Tool | iSpring. https://www.ispringsolutions.com/articles/key-advantages-ofvideo-lectures

Tupas, F. P., \& Linas-Laguda, M. (2020). Blended learning - An approach in Philippine basic education curriculum in new normal: A review of current literature. Universal Journal of Educational Research, 8(11), 5505-5512. https://doi.org/10.13189/ujer.2020.081154

Wairimu, M. J. (2016). Teachers' Perception on Classroom Observation and Checking of Pupils' Exercise Books by Head Teachers on Performance of Duty in Primary Schools in Nakuru North District, Kenya. Journal of Education \& Social Policy, 3(3), 1-8. 


\section{Appendix A \\ INTERVIEW PROTOCOL}

\section{Guide Questions}

\section{Practices of Secondary School Teachers in Preparing for Classroom Observation Amidst the New Normal of Education}

1. How important is performance evaluation for you as a teacher?

2. What do you think are the differences in the performance evaluation system before and during this new normal?

3. With the advent of the COVID-19 pandemic and the transition to distance learning, do you believe it is still appropriate to conduct a teacher performance evaluation? Why?

4. Which of the three options (1) Online Observation; (2) Observation of a video lesson; or (3) Observation of demonstration teaching via Learning Action Cell) of the New Normal Classroom Observation do you prefer to use? Why?

5. What are the techniques, strategies, and methods do you use in preparing the New Normal Classroom Observation?

6. What are the tools do you use in accomplishing the New Normal Classroom Observation?

7. Will you walk us through the process of how you conduct your teaching demonstration for the New Normal Classroom Observation?

8. What are the problems/difficulties do you encounter in preparing the New Normal Classroom Observation?

9. With respect to the manner you were rated using the New Normal COT, do you believe it is valid and reliable? What should be done to improve its implementation?

10. As a teacher, what is your impression regarding the overall quality of the demonstration teachings and the New Normal COTs?

\section{Concluding Script}

Thank you again for your time for this interview. The narrations and insights you have shared will be helpful in developing the research we are currently venturing into. In return, we are committing that we will be providing you the final 